\title{
Analysis of Oil Palm Plantation Sustainability Based on Indonesian Sustainable Palm Oil (ISPO) Standard at Plasma Plantation of PTPN XIII Ngabang, Landak Distric West Kalimantan Province
}

\author{
${ }^{1}$ Ani Muani, ${ }^{2}$ Dwidjono Hadi Darwanto, ${ }^{2}$ Lestari Rahayu Waluyati, ${ }^{2}$ Any Suryantini \\ ${ }^{1}$ Graduate Student of Departemen of Agricultural Economic, Agricultural Faculty, Gajah Mada University, Jl. Flora, Kompleks \\ Bulaksumur, Yogyakarta, DIY 55281, Indonesia. \\ ${ }^{2}$ Departement of Agrcultural Economics-Faculty of Agriculture, Gajah Mada University, Jalan Flora Kompleks Bulak Sumur, Yoyakarta, \\ DIY55281, Indonesia.
}

Received date: 19 July 2018, Accepted date: 15 August 2018, Online date: 1 September 2018

\author{
Address For Correspondence: \\ Ani Muani, Faculty of Agriculture, Tanjungpura University, Agribusinuss Study Program, Jl. Prof. Hadari Nawawi, Pontianak, West \\ Kalimantan, Indonesia. \\ E-mail: muani1951@gmail.com
}

Copyright $@ 2018$ by authors and American-Eurasian Network for Scientific Information.

This work is licensed under the Creative Commons Attribution International License (CC BY).

http://creativecommons.org/licenses/by/4.0/

\section{(c) (i) Open Access}

\begin{abstract}
To produce an environmentally friendly palm oil product, it is necessary to apply the concept of sustainable development in the management of palm oil from upstream to downstream. In an effort to improve the governance of oil palm plantations in Indonesia, the government has implemented an assessment instrument based on the system sustainability in the development of oil palm plantations namely Indonesian Sustainable Palm Oil-Certification System (ISPO-CS). This research was conducted at PT. Perkebunan Nusantara XIII, Ngabang Plantation Plasma, Landak District West Kalimanan. This research aimed at determine sustainability palm oil in Plasma plantations, based on sustainability index and status, and to identify sensitive attributes that affect the palm oil sustainability index menurut standar ISPO. The method used is RAP-ISPO (Rapid Appraisal for Indonesian Sustainable Palm Oil) with a Multi Dimensional Scaling (MDS) modification of the RAP-FISH program, which results are expressed in index and sustainability status. Leverage analysis is performed to identify sensitive attributes toward sustainability index. The result of RAP-ISPO analysis ordinary technique showed that a sustainabiliy index in multidimensional toward five dimensions of palm oil sustainability was classified as "sufficient sustainable" that indicated with a sustainability index value of 69.77. The highest value of sustainability index is in technological dimension was 81.91 (very sustainable), on the contrary the lowest value occurs in institutional dimension (53.80), social dimension (70.45), ecology (72.18) and the economy (70.44) are classified as quite sustainable. Identified 15 attributes of sensitivity / levers that affect the palm continuity. The conclusion of the research result that the plasma plantation of Ngabang has implemented ISPO although it is not optimal yet, but through improvement of 15 attributes of the levers, the status of palm oil sustainability can still be improved in order to produce economically viable, socially appropriate, and environmentally appropriate based on ISPO standard.

KEY WORDS

ISPO, plasma plantation, mutdimensions, sustainability index.
\end{abstract}

\section{INTRODUCTION}

Palm oil commodities have a strategic role in Indonesia's development, as a major driver of agribusiness development from upstream to downstream. Oil palm plantations and their derivatives are able to absorb a large number of workforces, more than 3.72 million heads of families absorbed in on-farm are also sources of income 
and State revenues from non-oil and gas exports, more from US \$ 17.3 billion (export value of palm oil greater than export value of agricultural products outside of palm oil) with export tax revenue of Rp 28.3 trillion. Other palm oil development benefits are linked to regional development and poverty reduction, the provision of cooking oil, biofuels, encouraging the development of domestic industries and producing the most efficient vegetable oils. The average income of small oil palm growers is seven times the income of farmers who rely on living from food crops. This is reinforced by World Growth findings in PASPI (2016), that the average income of palm oil growers is higher than non-palm oil farming; oil palm growers of $\$ 960$ / Ha, rubber farmers \$ 72 / Ha, rice farmers \$ 28 / Ha, cassava farmers \$ 19 / Ha.

The development of the Indonesian palm oil industry is accelerating as the area of Indonesia palm oil production is increasing rapidly from 300 thousand $\mathrm{Ha}$ in 1980 to 11.6 million ha in 2016, while CPO production increased from about 700 thousand tons in 1980 to 11 million tonnes in 2014 or increase about 18 times within six years [6]. Palm oil commodities have a strategic role in Indonesia's development, as a major driver of agribusiness development from upstream to downstream. Oil palm plantations and derivatives from upstream to downstream are able to absorb a considerable labor force, more than 3.72 million head of household absorbed in on-farm is also a source of foreign exchange and State income from non-oil and gas exports. Other palm oil development benefits related to regional development and poverty reduction, provision of cooking oil, biofuel [7].

The rapid development of oil palm plantations is feared to be one of the causes of environmental damage in the oil palm plantation area, this is allegedly due to monoculture planting of oil palm and the absence of a major component of forest vegetation includes forest trees, lianas and epiphytic orchid. In an effort to ensure the sustainability of the palm oil industry, the Government of Indonesia has enacted Regulation of the Minister of Agriculture No. 11 / Permentan / OT.140 / 3/2015) on Indonesia Sustainable Palm Oil-Certification System (ISPO). Indonesia Sustainable Palm oil Plantation (hereinafter referred to as ISPO) is a business system in the field of palm oil plantation that is economically feasible, socially appropriate, and environmentally friendly based on Indonesian legislation [13]. The principles of sustainability used in the ISPO scheme for Plasma plantation are: (1) Legality of plantation business, (2) Plantation management, (3) Environmental management and monitoring, (4) Responsibility for workers, (5) Social responsibility and community economic empowerment, and (6) continuous improvement of business. ISPO is a guidance for the development of Indonesia's sustainable palm oil plantations based on prevailing laws and regulations in Indonesia and responding to global market demands. The goal of the ISPO is to raise awareness about the importance of producing sustainable palm oil, increase the competitiveness of Indonesian palm oil in international markets, support Indonesia's commitment to reduce Greenhouse Gas (GHG) emissions and support unilateral Indonesian government commitments in Copenhagen (2009) Carbon up to $26 \%$ with International assistance and support. Thus ISPO is mandatory / obligation to be implemented by all business actors of oil palm plantation in Indonesia [8].

Sustainable development is agreed upon as a development that meets the needs of the present without sacrificing the right to meet the needs of future generations [3, 10,16). According to Munasinghe [13], the concept of sustainable agriculture is oriented towards three dimensions of sustainability: economic sustainability of business (Profit), sustainability of human social life (People), and sustainability of natural ecology (Planet). Jesinghaus (2007) uses an indicator he calls the dashboard of sustainable development using indicators that are used in four dimensions, social, economic, environmental and institutional. With reference to the concept of sustainable agriculture and the principles and criteria of ISPO, it can be determined five dimensions of palm oil plantation sustainability in this study covering dimensions: ecology, technology, social, institutional, and economic dimension.

Considering the problem of sustainable palm oil plantation management is a complex problem, the research of Sustainability of Palm Oil Plantation at Plasma Existing Plantation According to ISPO it is important to be done so that any technological, ecological, social, institutional and economic constraints that need to be anticipated and which indicators must be optimized in fulfillment of sustainability criteria can be fixed soon. Certification for plasma plantations is important as the quality and quantity of raw material supply from plasma plantations to Palm oil processing plants in Core Company is crucial to the sustainability of Indonesian palm oil according to ISPO standards, so that the research of Palm oil Sustainability According to ISPO in Plasma plantation is important.

\section{Research Method:}

\section{Study Location and Sampling:}

The location of the study was determined purposively at PIR V Kebun Ngabang PTPN XIII Landak District West Kalimantan Province, Indonesia Province. Data collection method is survey and by interviewing technique to plasma farmer (60 respondent) and indept interview to stakeholders as informant who controls judgment expert. Secondary data is obtained from related institutions (plasma manager office PTPN XIII Ngabang gardens about the evidence in the form of documents on the implementation of ISPO plasma plantations, local 
government, BPS, internet and relevant references related to the studied.The determination of the variables or dimensions of oil palm sustainability in plasma plantations is based on ISPO standards and the development of sustainable agriculture concepts that are oriented towards three dimensions of sustainability economy (Profit), sustainability of human social life (People), and natural ecological sustainability (Planet) and referring to the framework on the Commission on Sustainable Development, and relevant references related to the subject matter.

Data Analysis:

The sustainability analysis method used is Rap-ISPO which is a modification of Rapfish to assess the sustainability of the fishery system. Rapfish techniques use multi-dimensional scaling (MDS) statistical techniques to rapidly assess the status of existence or sustainability of a system. This technique is flexible enough so that it can be applied to the status assessment of Indonesian Sustainabe Palm Oil (ISPO) to (RapISPO). Rapid Appraisal Idonesian Sustaiable Palm Oil is a rapid analysis by building sustainability dimension indicators developed from the ISPO Principles and Criteria and the concept of sustainable agricultural development.

The MDS technique will perform multidimensional transformations into 2 dimensions and determine the relative sustainability position between 2 extremes in bad ordinate $(0 \%)$ and good $(100 \%)$ for each dimension or combined dimension. MDS principle is a distance measurement called euclidien distance. Distance (d) like the formula as follows:

$\mathrm{d}=([\mathrm{X} 1-\mathrm{X} 2] 2+[\mathrm{Y} 1-\mathrm{Y} 2] 2+[\mathrm{Z} 1-\mathrm{Z} 2] 2+\ldots$.

Where:

$\mathrm{d} 1,2=$ euclidian distance;

$\mathrm{X}, \mathrm{Y}, \mathrm{Z}=$ atribute

$1,2=$ treatment

The estimated score of each dimension is expressed on the worst (0\%) scale of $0 \%$ to the best (good) $100 \%$, grouped into four categories: 0-25\% categorized as bad (unsustainable), 25.01-50\% (less sustainable), 50.01$75 \%$ (sustainable enough) and 75.01-100\% are categorized as good (highly sustainable). Leverage analysis in MDS is performed to identify the sensitive attributes and the necessary interventions or improvements. Sensitive attributes are obtained based on the results of leverage analysis seen in the Root Mean Square (RMS) ordination change on the $\mathrm{X}$ axis. The larger the RMS value, the more sensitive the role of the attribute is to the improvement of the sustainability status. The ordination technique (distance determination) in MDS is based on eucledian distance in $\mathrm{n}$ dimensionless space. Euclidean distance is the square root of the amount of difference squared between the values of all items.

with the equation:

$d=\sqrt{\left(\left[X_{1}-X_{2}\right]^{2}+\left[Y_{1}-Y_{2}\right]^{2}+\left[Z_{1}-Z_{2}\right]^{2}+\cdots\right)}$

Where :

$\mathrm{d}=$ distance (distance between euclidian points)

$\mathrm{X} 1$ - X2: difference of attribute value $(\mathrm{X})$

Y1 - Y2: difference of attribute value (Y)

$\mathrm{Z} 1$ - Z2: difference of attribute value $(\mathrm{Z})$

In Rapfish, the regression process uses ALSCAL algorithm with the principle of making iteration of the regression process so as to produce the smallest error value. According to Fauzi and Ana [10] the ALSCAL algorithm optimizes square distance $=$ dijk to quadratic data (origin $=0 \mathrm{ijk}$ ) which in three dimensions $(\mathrm{I}, \mathrm{j}, \mathrm{k})$ is written in a formula called S-stress. MDS techniques also calculate the value of $\mathrm{S}$ stress to determine the goodness of fit of the model built. A good model has a S stress rating that is smaller than 0.25 [1, 10].

Dominant / sensitive factors for sustainability are characterized based on the results of leverage analysis that has been integrated into MDS. The value of S-stress and coefficient of determination $\left(\mathrm{R}^{2}\right)$ shows goodness of fit in MDS. Low S-stress values indicate goodness of fit while high S-stress values indicate otherwise. [11] suggest that a good model is if the $\mathrm{S}$-stress value is less than 0.25 and $\mathrm{R}^{2}$ approaches $1(100 \%)$.

$S=\sqrt{\frac{1}{m} \sum_{k=1}^{m}\left[\frac{\sum_{i} \sum_{j}\left(d_{i j k}^{2}-o_{i j k}^{2}\right)^{2}}{\sum_{i} \Sigma_{j} o_{i j k}^{4}}\right]}$

The position of the point of sustainability can be visualized in the form of kite diagram. The MDS principle is a distance measurement called euclidien distance. The point is then approximated by regressing the Euclidean distance from point $\mathrm{i}$ to point $\mathrm{j}$ with the origin (d) with equation: 
$\mathrm{d}=\mathrm{a}+\mathrm{bd}+\mathrm{e}$

In regression the above equations, least square techniques alternatingly are used based on the roots of eucledian distance (squared distance) or ALSCAL algorithm method. This method optimizes the squared distance to the quadratic data (origin $=0, \mathrm{k}$ ) in three dimensions $(\mathrm{j}, \mathrm{k}$ ) called $\mathrm{S}$-Stress with the following equation:

Goodness of fit in MDS is reflected in the magnitude of S-Stress and $\mathrm{R}^{2}$ values, a good model is shown by the $\mathrm{S}$-Stress value less than 0.25 and $\mathrm{R}^{2}$ approaching the value of one. A good model is if the $\mathrm{S}$-stress value is less than 0.25 and $\mathrm{R}^{2}$ is close to $1(100 \%)$. [11]

The output of the RAP-ISPO analysis is the sustainability index of 0-100 displayed in the ordination indicator and its effect. Sustainability indexes are grouped into four categories [1,4] ie at 0-25 intervals in bad (unsustainable) status; 25.01-50.00 in less status (less sustainable); 50.01-75.00 in sufficient status (sustainable enough); and 75.01-100.00 in good status (very sustainable).

\section{RESULTS AND DISCUSSION}

Results of Rap-ISPO analysis with multidimensional scaling (MDS) toward five dimensions those were ecology, technology, social, institutional, and economy are written down below:

\section{Index And Status Of Sustainability Of Oil Palm Ecological Dimension:}

The result of sustainability analysis using RAP-ISPO done on seven attributes that have an effect on the ecology dimension, obtained by the value of sustainability index of palm is $72,18 \%$ including sustainability criteria. Schematically the status of the ecological dimension or ordination of ecological dimensions is visualized in the form of RAP-ISPO ordination (Fig.1).

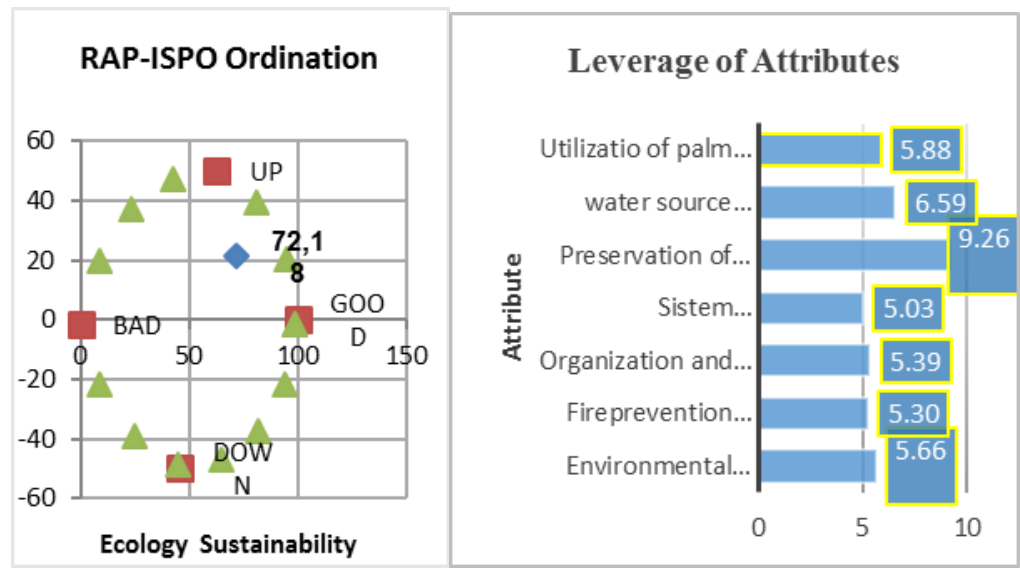

Fig. 1: Index Analysis and Sustainablity Status of Palm Oil Dimension Ecology and Sensitive Attributes that Affect Ecological Sustainability.

Based on the analysis of the leverage of ecological dimensions (Figure 1.), it is shown that the most dominant factor sensitive to palm oil sustainability is the preservation of biodiversity,and aquatic resources. Based on the results of the ecological dimension leverage analysis, indicating that the most dominant factor sensitive to oil palm sustainability is the preservation of biodiversity shown by the RMS (Root Mean Square) value at 9.26 which is followed by resource protection attributes watersources $(\mathrm{RMS}=6.59)$ and utilization of waste oil (RMS = 5.88). It means that if there is a change for an indicator with a small RMS value, it will not cause significant changes to the sustainability index. Conversely, if there is a slight change to the indicator with a large RMS value, it will cause significant changes to the sustainability index [1]

The result of ecological dimension leverage analysis shows that the first sensitive attribute to palm oil sustainability is biodiversity preservation, shown by RMS (Root Mean Square) value. It means that if an attribute change occurs with a small RMS value, it will not cause significant changes to the sustainability index. Conversely, if there is a slight change to the indicator with a large RMS value, it will cause significant changes to the sustainability index. The sensitive attribute "biodiversity conservation" is the first sensitive factor for the sustainability of the ecological dimension that should be given due attention, as oil palm plantations to date are categorized as one of the causes of declining biodiversity diversity, so this issue needs to be addressed. In ISPO Principles and Criteria number 3.3. on Biodiversity Conservation; ensure that farmers, farmer groups know the protected species in the area and the region's existence. However, in reality the level of plasma farmers has not yet realized the importance of biodiversity conservation and has not recorded the efforts made by farmers, farmer groups and cooperatives to implement the conservation of animals and plants in the region. 
The ISPO Criteria has required that every palm oil plantation is required to have a High Conservation Value (HCV) area. Such conditions indicate to the authorities (the Company and local government) to conduct campaigns and socialization more intensively to the community about the importance of biodiversity pelesterarian in the region so that through the environmentally friendly palm oil industry will be able to improve the welfare of society in a sustainable economy [19]. The second sensitivity attribute, the conservation of water resources in the palm oil plantation and plantation areas should be considered, especially in the case of water quality degradation caused by the processing of FFB into the CPO at the factory. Therefore, environmental monitoring on the quality of water resources, among others, river water where the waste disposal that has been filtered according to required standards must be done continuously, so that water used by the community is safe and the life of the fishery resources in the waters is guaranteed. In relation to efforts to prevent and mitigate the negative impacts of water quality degradation caused by palm waste, PTPN XIII Kebun PIR V Ngabang and PMS Unit Ngabang have conducted the construction of Waste Management Installation (IPAL) equipped with sediment ponds with benchmarks of the value of liquid waste coming out of the outlet the factory does not exceed the BML stipulated by Kepmen.LH number 51 / MENLH / 10/95 and Governor's Decree no. 26/2002 [14].

The thirdth sensitive attribute palm oil is plantation waste. It is known that a ton of oil palm is able to produce waste in the form of oil palm empty fruit bunches (OPEFB) of $23 \%$ or $230 \mathrm{~kg}$, $6.5 \%$ shell waste or 65 $\mathrm{kg}$, wet decanter solid (oil mud) of $4 \%$ or $40 \mathrm{~kg}, 13 \%$ of fiber or $130 \mathrm{~kg}$ and liquid waste as much as 50\% [18]. Palm waste is an organic waste that is easily processed into organic fertilizer and includes a safe environment. Therefore, the utilization of palm oil is very important for the purposes of chemical fertilizer replacement so that sustainable palm oil sustainability can be realized. In addition to environmentally friendly, palm waste utilization can also reduce production costs (cost efficiency) because it can replace chemical fertilizers that cost higher. While the palm oil processing industry will produce residues and residues as waste oil, which consists of solid waste in the form of palm fruit bunches (tankos), and waste water. Palm waste is an organic waste that is easily processed into organic fertilizer and includes a safe environment. Therefore, the utilization of palm oil is very important for the purposes of chemical fertilizer replacement so that sustainable palm oil sustainability can be realized. In addition to environmentally friendly, palm waste utilization can also reduce production costs (cost efficiency) because it can replace chemical fertilizers that cost higher. The rapid expansion of oil palms will be accompanied by significant increase of palm oil waste, so that if not handled soon will cause environmental pollution problems. At the study site, solid waste oils in the form of empty fruit bunches (tankos) are utilized by plasma farmers as organic fertilizer used for palm plantation, also for vegetable crops in the yard.

\section{Index And Status of Palm Oil Sustainability Technology Dimensions:}

The results of RAP-ISPO analysis conducted on 12 attributes affecting the sustainability dimension of palm oil technology, the value of sustainability index technology dimension is obtained: 81.92 , it means it is included in the status very sustainable. The result of leverage analysis for technological dimension visualized in the form of picture (Figure 2), three attributes of leverage to palm oil sustainability technology dimension that is: plant maintenance, timing of transportation of Fruit Fresh Brand (FFB/TBS)) from plantation and attribute of land clearing without burning.

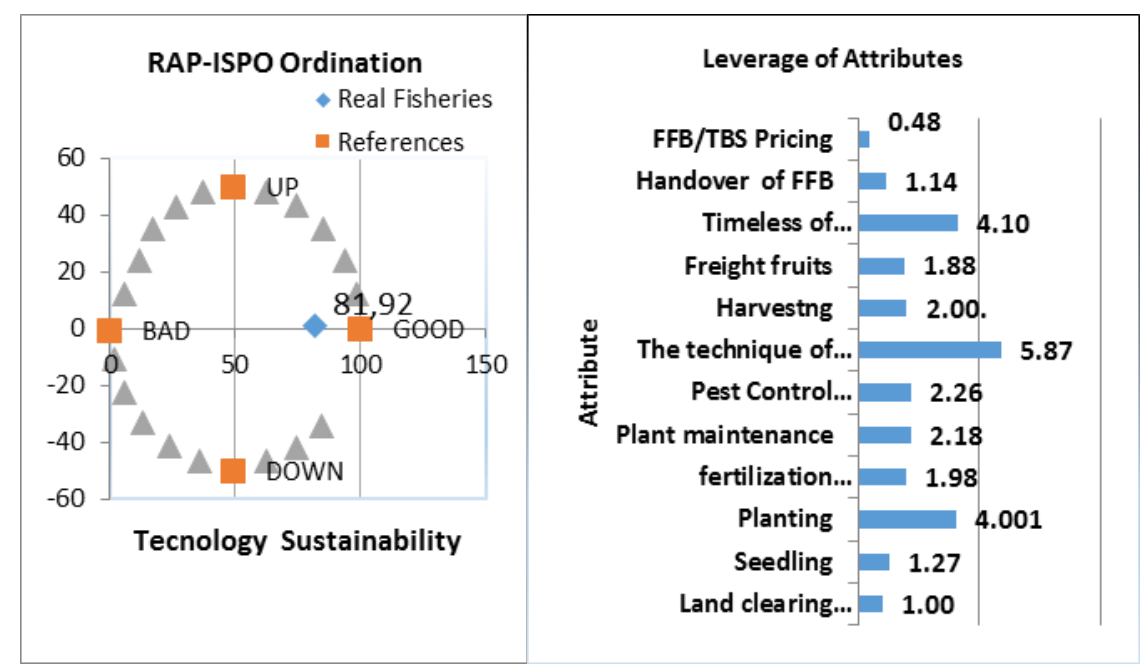

Fig. 2: Index Analysis and Sustainablity Status of Palm Oil Dimension Technology and Sensitivite Attributes that Affect Technology Sustainability. 
The result of leverage analysis on 12 technological dimension attributes obtained three attributes that are sensitive to the level of oil palm plantation sustainability for technology dimension are: (1) plant maintenance (2) timely transportation of TBS from plantation to factory, and (3) land clearing without burning.

The first sensitive attribute of technological dimension is the technique of pest organism, it is very important to note because the activities on pest organism will greatly determine the productivity of palm oil that is produced in the long term [14]. The second sensitive attribute is the timeliness of transporting FFB (Fresh Fruit Bunches) from plantation to palm oil mills, including one of the three most important links in oil palm cultivation including harvesting, transport, and processing. If FFB is late to be processed, due to delayed transportation can increase free fatty acid (FFA), the higher the content of FFA the lower the quality of CPO. According to Pahan [11], that the production of fruit with good quantity will produce CPO yield of 23.2-27.4 percent with FFA content less than 3 percent $(<3 \%)$. The higher the FFA content, the lower the quality of CPO. The attribute is the unfueled land clearing, which is very important, as an effort to reduce deforestation and greenhouse gas emissions (GHG), which is set out in the ISPO Principles and Criteria number: 2.2.1. about Land Opening. The clearing of plasma plantation land of Ngabang PTPN XIII has been referring to SOP Number: SOP / 13.01-01 / 2011 concerning land clearing / LC and oil palm plantation, completed by Working Instruction Number: 13.01-01.05 concerning land clearing and tillage with principle zero.

\section{Index And Status Of Sustainability Of Palm Oil Social Dimension:}

The RAP-ISPO analysis on seven attributes that influence the sustainability of palm oil social dimension resulted in a sustainability index value of: 70.45 percent means included into sustainable enough status. Identified three sensitive attributes that can be a leverage factor against the social dimension index value: HDI, the implementation of Occupational Safety and Health (K3) and attributes of the unemployment rate of the population.

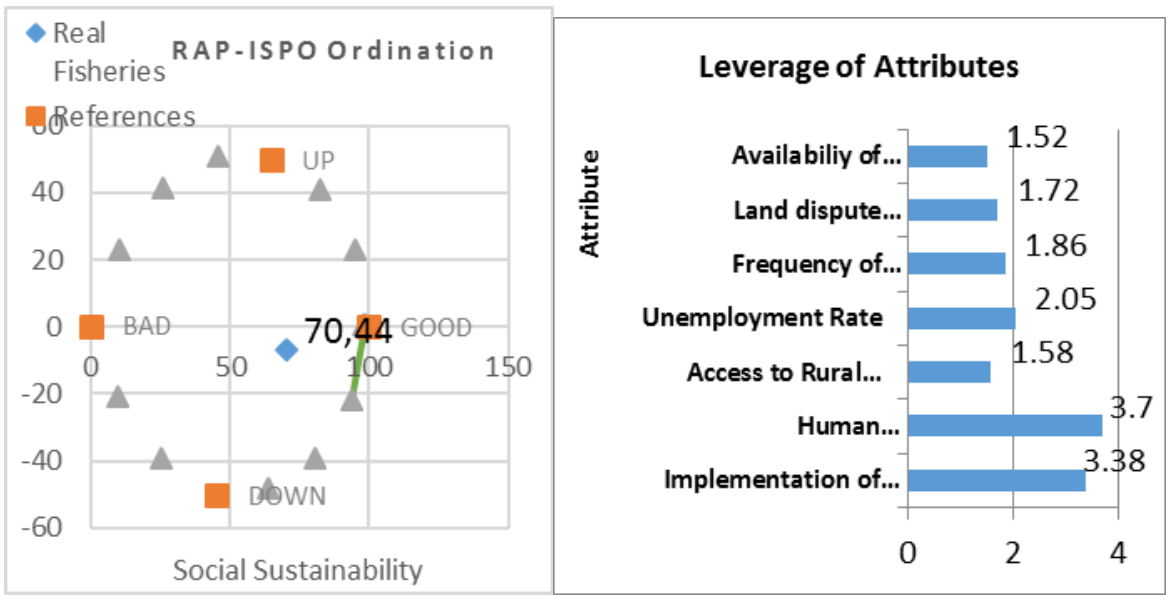

Fig. 3: Index Analysis and Sustainablity Status of Palm Oil Social Dimension and Sensitive Attributes that Affect Social Sustainability.

The first sensitive attribute is the Human Development Index (HDI) is very important to be improved continuously, because HDI is used to measure the success rate of human development, and the influence of economic policy on the quality of human life that can describe the four components of life expectancy representing health, literacy rates and the average length of school measuring educational achievements in education, and the purchasing power / purchasing power (PPP) of the community against a number of basic needs seen from the average per capita expenditure as an income approach representing the achievement of development to live worthy.

The application of Occupational Safety and Health (K3) for sustainability of coconut is needed to improve the quality of life of workers through health and safety (K3) guarantee and safe, peaceful and healthy work situation. Through the application of $\mathrm{K} 3$, it will be able to encourage workers to be more efficient and productive as required in ISPO Principles and Criteria number 4 in Permentan no. 11 of 2015. Potential hazards for workers, in the oil palm plantation industry are in the process of land clearing, planting, crop maintenance and harvesting. Through improvement of OSH implementation, the sustainability of oil palm in plasma plantations according to ISPO standards can be improved to be highly sustainable.

The third sensitive attribute is the population unemployment rate, an important social issue as it relates to the availability of employment and population. Landak District has a young population because about half of the total population under the age of 30 years requires a lot of employment. Data of Landak Regency BPS [2] shows 
that unemployment rate of Landak District resident in 2011 is $3.18 \%$ increase to $6.81 \%$ in 2015 . It means that there is an increase in unemployment rate in Landak District for the last five years. This condition indicates that job creation for the people in this area is very important to be prioritized in development in Landak District.

\section{Index And Status Of Sustainability Of Oil Palm Institutional Dimensions:}

The results of RAP-ISPO analysis conducted on eight attributes affecting the sustainability of palm oil institutional dimension resulted in a sustainability index score of 53.80 percent including into sustainable enough status.

The first sensitive attribute is farmer access to information, it is very important to note because it is related to the bargaining position of producer farmers in determining the price of the product that is TBS produced. Bargaining position of farmers is suspected due to weak farmers in accessing price information, market demand, product demand, and cultivation technology. Access to pricing and technology information can be obtained through Agricultural Extension and by utilizing information technology. The second sensitive attribute is the training and assistance/coaching of palm oil cultivation technology to plasma farmers by partner companies. Assistance to the application of palm oil cultivation technology should be carried out continuously to the plasma farmers, both before and after conversion. In the period before the conversion of plasma plantation, farmers continue to be given training and mentoring of technology cultivation refers to Principles and Criteria ISPO number 2.2. on the Implementation of Cultivation and Transportation Technical Guidelines. However, postconversion, plasma farmers no longer provided training and assistance in the management of the garden. As a result, in post-conversion plasma plantation there is a decrease in the productivity of palm oil crops declining and far from their potential productivity.

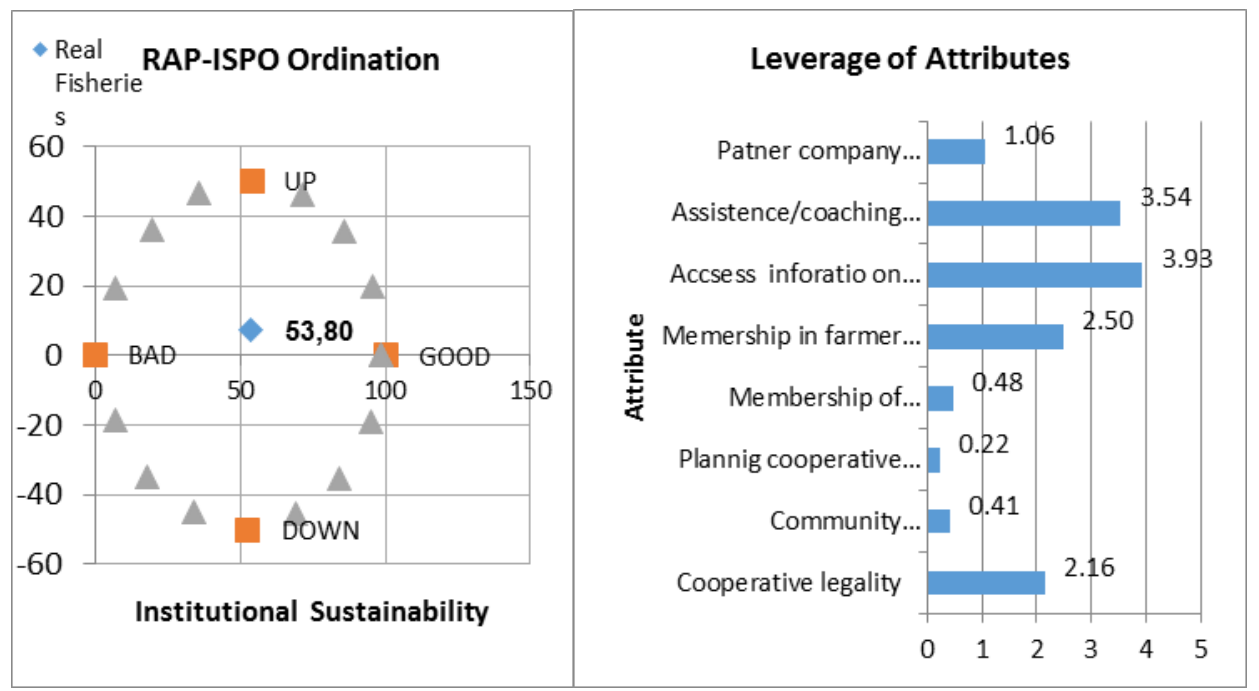

Fig. 4: Index Analysis and Sustainablity Status of Palm Oil Institutional Dimension and Sensitive Attributes that Affect Institutional Sustainability.

The third sensitive attribute on the importance of farmer group institutions, because it is a vital container of activities in improving knowledge, skills and attitudes of farmers to the application of technical cultivation of palm oil environmentally friendly. Through the empowerment of farmer groups, while at the same time improving the efficiency of production costs, increasing productivity which in turn will increase the income and welfare of farmers. The reality in the field, at this time the existence of farmer group institutions in the research location is felt not able to provide optimal benefits for its members, due to lack of guidance to farmers' groups in the plasma garden post conversion from related parties. Therefore, assistance to farmers' group of plasma farmers after conversion by partner companies is still not decided by partner companies in plasma plantation post-conversion.

5. Index And Status Of Palm Oil Sustainability Economic Dimension:

The results of Rap-ISPO analysis performed on seven attributes affecting the sustainability of the economic dimension resulted in a sustainability index value of $70.44 \%$, it means that it belongs to a fairly sustainable category $[1,4]$. Identified three attributes that are sensitive to the level of oil palm plantation sustainability are: the level of productivity of FFB, access to business capital; and the number of poor people. 


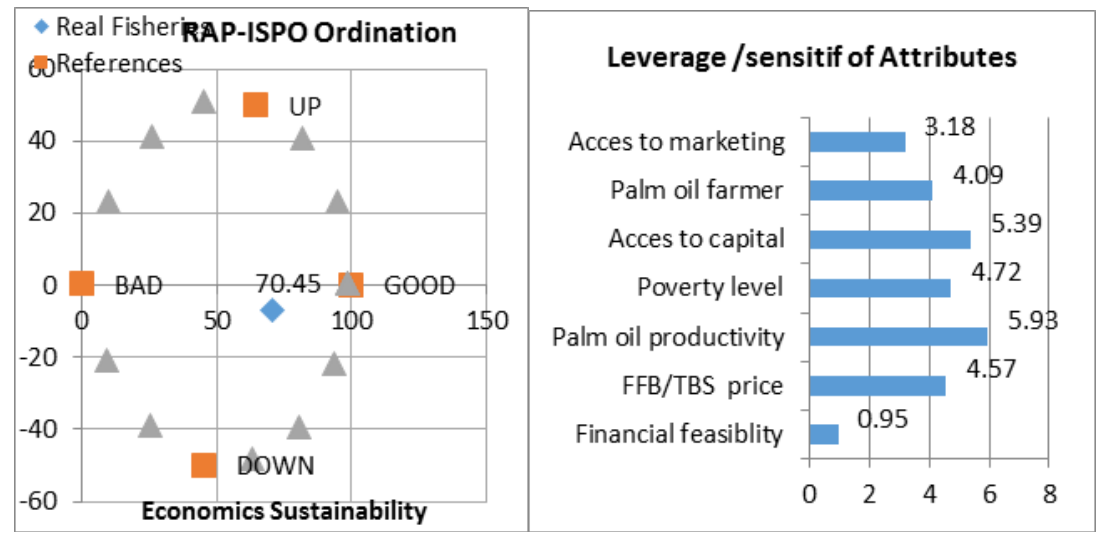

Fig. 5: Index Analysis and Sustainablity Status of Palm Oil Economic Dimension and Sensitivite Attributes that Affect Economic Sustainability.

The first sensitive attribute of the economic dimension is the productivity of FFB, the problem of decreasing the productivity of the plasma plantation occurs after the conversion of plasma plantation, mainly because the management of the garden is the responsibility of the smallholders, while the partner companies are not responsible for the guidance of the smallholders. The problem of decreasing the productivity of smallholder plasma FFS appears after post-conversion of plasma plantation, mainly because the management of the garden is the responsibility of the smallholders, while the partner companies are not responsible for the development of smallholders. Due to the poor physical condition of the plants are not maintained and fertilization implemented not in accordance with technical provisions, maintenance of less attention to the productivity of plasma garden FFB decreased dramatically. Therefore, sustainability of assistance by partner companies and related institutions is required to the smallholders of Ngabang Landak plantation in the application of technology of oil palm cultivation continuously after conversion of plasma plantation. Access to business capital is a sensitive attachment that must be considered because in general the farmers lack access to capital for the purchase of production facilities and maintenance costs of palm oil crops, especially during replanting.

The lowest sensitive attribute in the sustainability of the plasma plantation's economic dimension is financial feasibility, it means that palm oil plantations are financially viable despite the changes in price reduction and increased production costs in terms of Net Present Value ( NPV), Net Benefit Cost Ratio (Net B / C) and Internal Rate of Return (IRR).

6. Index And Status Of Palm Oil Sustainability Multi Dimension:

The results of multidimensional RAP-ISPO analysis of oil palm plantation of Ngabang PTPN XIII palm oil as a whole (multidimensional) obtained 69.77 value, that is it belongs to either good or sustainable category. This value is derived based on the assessment of attributes that include ecological, technological, social, institutional and economic dimensions with 41 attributes that influence the sustainability of palm oil plantations according to the modified ISPO principles and criteria. Through the MDS method, the sustainability point position can be visualized in the form of a kite diagram (Figure 6). The highest value is seen in the technological dimension of 81.91 including the category of highly sustainable, on the contrary the lowest value occurs in the institutional dimension (53.80) but still in the category is quite sustainable.

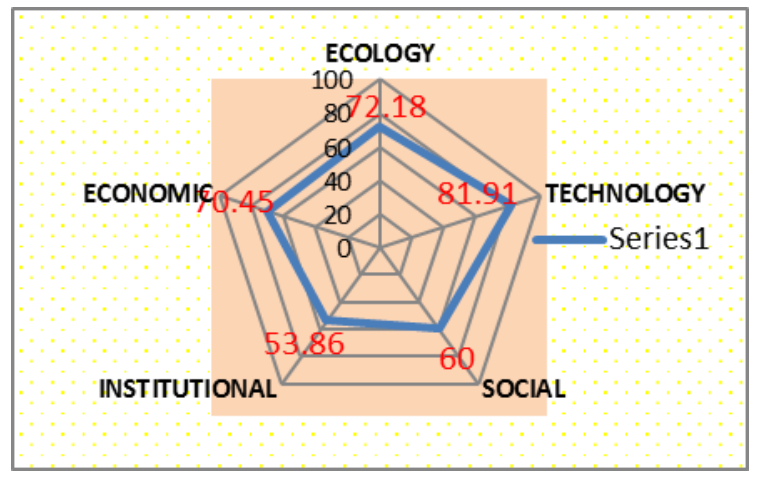

Fig. 6: Kite Diagram Multy Dimension Palm Oil Sustainability Indexs. 
To know the status of sustainability in each dimension, it is necessary to do RAP-ISPO analysis on each dimension, as follows in Table 1.

Table 1: Results of multydimension palm oil sustainability index analysis.

\begin{tabular}{|l|l|l|l|l|}
\hline Dimension & Sustainability index & Value of Stress & $\begin{array}{l}\text { Diferent MDS and Monte Carlo } \\
\text { analysis }\end{array}$ & $\mathrm{R}^{2}$ \\
\hline Ecology & 72.18 & 0.14 & -0.08 & 0.95 \\
\hline Technology & 81.91 & 0.13 & 0.48 & 0.96 \\
\hline Social & 60.00 & 0.14 & -0.43 & 0.95 \\
\hline Institutional & 53.80 & 0.14 & 0.66 & 0,95 \\
\hline Economy & 70.45 & 0.14 & 0.47 & 0.95 \\
\hline
\end{tabular}

Source: RAP-ISPO Analysis , 2017

The validation of RAP-ISPO simulation results for the five dimensions presented in Table 2 with the value of determination coefficient $\left(\mathrm{R}^{2}\right)$ of 0.95 means that the attributes assessed in each dimension are able to explain and contribute $95 \%$ to the sustainability of the system studied, the magnitude of $\mathrm{S}$ (stress) the fifth dimension can represent a well-valued model, the stress value is said to be good if its value below 0.25 means the value of goodness of fit in MDS states that the attribute configuration can reflect the original data [1]. Thus, the value of the palm oil sustainability index can still be upgraded to a very sustainable status by improving the sensitive attributes of the ecological, technological, social, institutional and economic dimensions.

Conclusions and Recommendations:

1. Plasma plantations Ngabang PTPN XIII has enacted Regulation of the Minister of Agriculture No. 11 / Permentan / OT.140 / 3/2015) on Indonesia Sustainable Palm Oil-Certification System (ISPO)

2. The management of oil palm plantations in the plasma pattern of PIR V Ngabang classified as sufficient sutainable The highest value of sustainability index is in technological dimension (very sustainable), on the contrary the lowest value occurs in institutional dimension, social dimension, ecology and the economy are classified as quite sustainable. Multidimensionally, the management of the Ngabang plasma plantation is also classified as sufficient sustainable.

3. Sensitive attributes that affect the sustainability of palm oil management system in Ngabang plasma plantation include 15 attributes, in each dimension: (1) Ecology (conservation diversity, water source protection, palm oil utilization), (2) Social (Human Development Index, Application of OHS, corporate communications with farmers, and unemployment rate, (4) Institutional (Access to price information, farmer group activity, and technology training ); (5) Economic Dimensions (palm oil productivity, access to venture capital, and the level of the poor). Identified 15 attributes of sensitivity that affect the palm oil sustainability but through improvement of 15 attributes of the levers, the status of palm oil sustainability can still be improved in order to produce economically viable, socially appropriate, and environmentally appropriate based on ISPO standard.

4. The application of ISPO will be more effective through assistance to smallholders in the replanting program, because it is the right time for the technical implementation of oil palm cultivation that is ecologically economically and socially feasible according to ISPO principles and criteria so that it can produce environmentally friendly or sustainable palm oil raw materials

\section{REFERENCES}

[1] Alder, J., T.J. Pitcher, D. Preikshot, K. Kaschner and B. Feriss, 2000. How Good is Good?: A Rapid Appraisal Technique for Evaluation of The Sustainability Status of Fisheries of The North atlantic, pp: 136182. Sea Around Us Methodology Review. Fisheries Centre, University of British Columbia, Vancouver Canada.

[2] Badan Pusat Statistik Kabupaten Landak, 2017. Landak Dalam Angka 2016. BPS Kabupaten Landak.

[3] Brundtland, G. Harlem, 1987. Our Common Future, New York: Oxford University Press.

[4] Budiharsono, S., 2014. Rapid Assesmentt Techniques for Locl Economic Development dan Program Penentuan Bobot untuk Aspk Pengembangan Ekonomi Lokal. Direkttorat Perekonomian Daerah BAPPENAS. Jakarta.

[5] Dirjen Perkebunan Kementrian Pertanian, 2014. Kebijakan Perkebunan Kelapa Sawit Berkelanjutan (ISPO) Sosialisasi Draft Pedoman ISPO Untuk Kebun Plasma (http://bahanispoplasma,zip-InRar diakses 12 Mei 2017).

[6] Dirjen Perkebunan Kementrian Pertanian, 2015. Perkebunan Kelapa Sawit Berkelanjutan Indonesia (Indonesian Sustainale Palm Oil). Persyaratan Untuk Kebun Plasma. Tim ISPO Kementrian Pertanian (.http://www.ispo-org.or.id/images/Persyaratan_ISPO-Plasma-revisi_23_Januari_2013.1.pdf) diakses 15 Januari 2015. 
[7] Fauzi, A. dan S. Anna, 2004. Evaluasi Status Keberlanjutan Pembangunan Perikanan: Aplikasi Pendekatan RAPFISH (Studi Kasus Perairan Pesisir DKI Jakarta). Pesisir dan Lautan, 4(3): 43-55.

[8] Fisheries Centre, 2002. Attributes of Rapfish Analysis for Ecologicl, Technologica, Economic, social nd Etica Evaluation Fields. Institute of Social and Economic. Research Press. St John's Canada.

[9] Gallopin, G., 2003. A System Approach to Sustainablity and Sustainable Development and Human Settlement Division. Nacions Unidas Santiago.Chili.

[10] Kementtrian Petanian, ISPO Commision, 2015. Peraturan Menteri Pertanian Republik Indonesia Nomor: 11/Permentan/OT.140/3/2015 tentang Sistem Sertifikasi Kelapa Sawit Berkelanjutan Indonesia (Indonesian Sustainable Palm Oil/ISPO).

[11] Kavanagh, P., T.J. Pitcher, 2001. Implementing Microsoft Excel Software For Rapish: A Technique For The Rapid Appraisal of Fisheries Status. University of British Columbia, Fisheries Centre Research Reports.12 (2).

[12] Malhotra, N.K., 2000. Riset Pemasaran : Pendekatan Terapan. PT Indeks Gramedia.Jakarta.

[13] Munasinghe M., 1993. Environmental Economic and Sustainable Development. The International Bank for Reconstruction and Development/The World Bank, Washington D.C. 20433, USA.

[14] Mitchel, B., B. Setiawan, D.H. Rahmi, 2000. Pengelolaan Sumberdayadan Lingkungan Gajah Mada University Press.

[15] Pahan, I., 2007. Panduan Lengkap Kelapa Sawit, Manajemen Agribisnis dari Hulu hingga Hilir. Penebar Swadaya. Jakarta.

[16] Palm Oil Agribusiness Strategic Policy Institute (PASPI), 2016. Mitos vs Fakta Industri Minyak Sawit Indonesia dalam Isu Sosial, Ekonomi dan Lingkungan Global. PASPI, pp: 168.

[17] Pitcher, T.J. and D.B. Preikshot, 2001. Rapfish: A Rapid Appraisal Technique to Evaluate the Sustainability Status of Fisheries. Fisheries Research, 49(3): 255-270.

[18] Smith, C.S. and G.T. Mc. Donald, 1998. Accesing The Sustainability of Agriculture at The Planning Stage. Journal of Environmental Management, 52: 15-37.

[19] Santosa, Y., A. Perdana, 2017. Kawasan Nilai Konservasi Tinggi dalam Pelestarian Keanekaragaman Jenis Mamalia Di Perkebunan Kelapa Sawit: Studi Kasus Provinsi Riau. Pros Sem Nas Masy Biodiv Indon, 3(1): 81-87. 